\title{
AN ECONOMETRIC ANALYSIS OF VALUE ADDITION IN CHILLY INDUSTRIES IN SOUTHERN TAMIL NADU
}

\author{
DR. N. CHITRA
}

Assistant Professor, Department of Mathematics, Thiagarajar College of Engineering, Madurai

\begin{abstract}
The study was an attempt to estimate economics of chili powder and sauce production in major chilly marketing area in Southern Tamil Nadu. Further optimization technique was used to analyse the resource allocation in chillies industries. It was found that cost of production of chilli powder was Rs. 30.15/ pocket (200 gm/pocket) and the profit earned was estimated as Rs. 14.85per pocket of chilli powder product. Whereas cost of production of chilli sauce was Rs. 31.02/ pocket (200 gm/pocket) and the profit earned was estimated as Rs. 8.98 per pocket of chilli sauce product. The establishment of rural chillies processing industry as a cooperative venture, covering about 1000 chillies growers (5-10 villages) was also found to be economically viable. The linear program analysis indicted that 47,945 Chillies powder pockets/year should be produced @ 160 pockets (200 gm pockets) per day. It fetched the gross income accounting for Rs.21.57 lahks /year. Further It would save the chilly industry scarce resources towards effective supply chain optimization.

KEYWORDS: Supply Chain Optimization-Linear Programming-Chillies Processing Industry
\end{abstract}

Received: Jun 06, 2020; Accepted: Jun 26, 2020; Published: Aug 21, 2020; Paper Id.: IJMPERDJUN2020841

\section{INTRODUCTION}

India is popularly known as "Spice bowl of the world" and is the largest producer, consumer and exporter of spices. India is the world leader in chilli production followed by China, Thailand, Ethiopia and Indonesia. Indian chilli is considered to be world famous for two important commercial qualities of color and pungency levels. Indian chilli is mainly exported to Asian countries like Vietnam, Thailand, Sri Lanka, Bangladesh and U.A.E. In India, major chilli producing states are Andhra Pradesh, Telangana, Tamil Nadu, Karnataka and Madhya Pradesh. Red Chilli production for 2019-20 is estimated at 12.00 lakh MT compared to earlier estimate of 12.45 lakh MT, while previous year's production was 10.50 lakh.Currently, India is the main source of red chilli in the international market. It exports in different forms like chilli powder, dried chilli, pickled chillies and chilli oleoresins. In this background, an attempt has been made with the specific objectives: (i) to analyse economics of chilly powder and sauce production and (ii) to determine the optimal allocation of chilly industry scarce resources in Southern Tamil Nadu.

\section{METHODOLOGY}

In Southern Tamil Nadu, Virudhunagar district is known for Chillies industries. Hence three leading chillies industries producing value added products were purposively selected to collect data on Chillies industry scarce resources, production and marketing of Chillies products. The data were collected in person to estimate economics of chillies powder and sauce production and to estimate optimum resource allocation. In linear programming, 
Simplex model was applied to determine the optimal allocation of scarce chillies industry resources.

\section{Linear Programming Problem}

Standard form is the usual and most intuitive form of describing a linear programming problem. It consists of the following three parts:

\section{A Linear Function to be Maximized}

e.g. maximize $c_{1} x_{1}+c_{2} x_{2}$

Where maximize income from value addition in Chillies industry $c_{1}$ and $c_{2}$ are coefficients ( price/unit)

$\mathrm{x}_{1}$ and $\mathrm{x}_{2}$ are Chillies powder and Chillies Sauce products

Problem constraints of the following form

$$
\begin{aligned}
& a_{11} x_{1}+a_{12} x_{2} \leq b_{1} \\
& a_{21} x_{1}+a_{22} x_{2} \leq b_{2} \\
& a_{31} x_{1}+a_{32} x_{2} \leq b_{3}
\end{aligned}
$$

where

$\mathrm{a}_{11}$ and $\mathrm{a}_{12}$ are human labour requirement/unit ;

$\mathrm{a}_{21}$ and $\mathrm{a}_{22}$ are capital requirement/unit

$\mathrm{a}_{31}$ and $\mathrm{a}_{32}$ are demand for respective products

$b_{1} b_{2}$ and $b_{3}$ are resource avilable in the industry

\section{Non-Negative Variables}

e.g.

$$
\begin{aligned}
& x_{1} \geq 0 \\
& x_{2} \geq 0
\end{aligned}
$$

The problem is usually expressed in matrix form, and then becomes:

$$
\operatorname{Maximize} \mathbf{c}^{\mathbf{T}} \mathbf{x}
$$

Subject to

$$
\mathbf{A x} \leq \mathbf{b}, \mathbf{x} \geq 0
$$

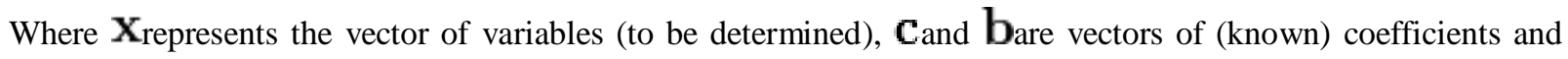

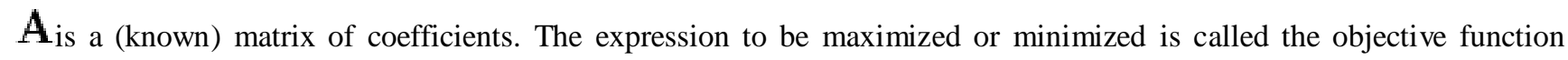

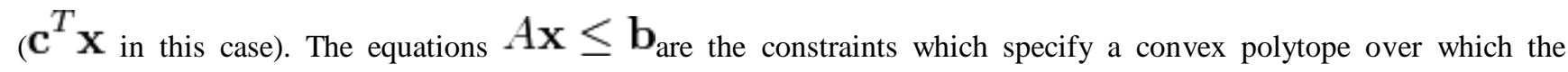
objective function is to be optimized. 


\section{RESULTS AND DISCUSSION}

The study results were revealed that economics of value addition in chillies industry and optimization paved the way for better utilization of scarce resource in these industries. The results were discussed as follows:

\section{Economics of Value Addition in Chillies Industry}

The Economics of value addition in Chillies Industry was studied in two major value added products namely chillies powder and chillies sauce.

\section{Economics of in Chillies Powder Production}

The study was conducted to analyse economics of Chillies powder production and the results were discussed in table 1 . Since the arrival of chillies was seasonal, the economics was worked out for 300 days/year. Economics of dry chillies powder production for the unit with a production capacity 160 pockets (200 gm/pocket) per day was estimated for 300 days per year. The initial investment expenditure was Rs. 16.55 lakhs for the above mentioned plant. The total fixed cost (operation and maintenance cost) was Rs. 2.53 lakhs for the processing plant. The total variable cost (running cost or production cost) was worked out as Rs. 11.39 lakhs. Here the value of dry chillies was arrived by multiplying the price during the peak arrival season and the total quantity of raw chillies materials used. The annual total cost of processing was Rs.14.47 lakhs. The gross return was estimated for production of chillies powder was Rs. 21.60 lakhs/year. Here the market price of dry chilli powder product was used as Rs. 45/pocket. It was further found that cost of production of chilli powder was Rs. 30.15 / pocket (200 gm/pocket). Further, the profit earned was estimated as Rs. 14.85per pocket of chilli powder product.

Table 1: Economics of in Chillies Powder and Sauce Production (160 pockets(200gms)/day for 300 days)

\begin{tabular}{|c|c|c|c|c|}
\hline \multirow{3}{*}{ S. No. } & & \multicolumn{2}{|c|}{ (in Lakh Rupees) } \\
\hline & & & Chilli Powder & Chilli Sauce \\
\hline & \multicolumn{2}{|r|}{$\begin{array}{c}\text { Particulars } \\
\text { Establishment of processing unit }\end{array}$} & Amount & Amount \\
\hline & 1 & Land and Building Value & 10.000 & 10.000 \\
\hline & & Cost of processing machines and accessories & 5.500 & 5.500 \\
\hline & & Office furniture and Fixtures & 0.750 & 0.750 \\
\hline & & Transport and installation charges & 0.300 & 0.300 \\
\hline & & Total establishment expenses & 16.550 & 16.550 \\
\hline & & Annual share of establishment cost & 0.550 & 0.550 \\
\hline \multirow[t]{17}{*}{ II. } & \multicolumn{2}{|r|}{ Annual Processing Expenditure } & & \\
\hline & a. & & & \\
\hline & 1 & Cost of dry chillies & 7.790 & 8.604 \\
\hline & 2 & Labour charges (wages) & 1.400 & 1.464 \\
\hline & 3 & Cost of electricity, fuel and Water & 0.250 & 0.275 \\
\hline & 4 & Packaging materials and packing charges & 0.800 & 0.975 \\
\hline & 5 & Transport Charges & 0.300 & 0.300 \\
\hline & 6 & Marketing and advertising charges & 0.200 & 0.200 \\
\hline & 7 & Interest on working capital@ 12 percent & 0.650 & 0.742 \\
\hline & & Annual variable cost or running cost & 11.390 & 12.360 \\
\hline & & Annul variable cost or running cost (Rs./Pocket) & 23.73 & 25.75 \\
\hline & b. & Total Annual Fixed cost & & \\
\hline & 1 & Salary of permanent staff & 1.500 & 1.500 \\
\hline & 2 & Maintenance cost of processing unit and building & 0.100 & 0.100 \\
\hline & 3 & Management cost & 0.250 & 0.250 \\
\hline & 4 & Building rental value & 0.200 & 0.200 \\
\hline & 5 & Depreciation on machineries & 0.170 & 0.170 \\
\hline
\end{tabular}




\begin{tabular}{|c|c|c|c|c|}
\hline & 6 & Interest on fixed investment & 0.310 & 0.310 \\
\hline & & $\begin{array}{l}\text { Total annual fixed cost } \\
\end{array}$ & 2.530 & 2.530 \\
\hline \multirow[t]{7}{*}{ III. } & & $\begin{array}{c}\text { Total annual processing cost } \\
\text { (Annual share of Establishment cost + AFC + AVC) }\end{array}$ & 14.470 & 14.890 \\
\hline & & Production/year@160 pocket/day for 300 days (lakh pocket) & 0.480 & 0.480 \\
\hline & & Price/pocket (Rs./pocket) & 45.000 & 40.000 \\
\hline & & Gross income / year & 21.600 & 19.200 \\
\hline & & Profit / year & 7.130 & 4.310 \\
\hline & & Cost of production / pocket (Rs./pocket) & 30.15 & 31.02 \\
\hline & & Profit / pocket (Rs./pocket) & 14.85 & 8.98 \\
\hline
\end{tabular}

In nutshell, the establishment of rural chillies processing industry as a cooperative venture, covering about 1000 chillies growers (5-10 villages) was also found to be economically viable. Of the initial investment of Rs.16.55 lakh required for establishing the processing unit, Rs 6.55 lakhs may be contributed by 1000 farmers at the rate of Rs.655 per farmer for each hectare of chillies. The remaining 10 lakhs and the working capital requirements in the initial stages could be obtained from NABARD by submitting proper project proposals. Educating the farmers about the advantage of collective processing is very important to solicit their cooperation and NGOs could play a significant role in organizing the farmers.

\section{Economics of in Chillies Sauce Production}

The study was conducted to analyse economics of Chillies Sauce production and the results were discussed in the table 1 . Since the arrival of chillies was seasonal, the economics was worked out for 300 days/year. Economics of dry chillies sauce production for the unit with a production capacity 160 pockets ( $200 \mathrm{gm} /$ pocket) per day was estimated for 300 days per year. The initial investment expenditure was Rs. 16.55 lakhs for the above mentioned plant. The total fixed cost (operation and maintenance cost) was Rs. 2.53 lakhs for the processing plant. The total variable cost (running cost or production cost) was worked out as Rs. 12.36 lakhs. Here the value of dry chillies was arrived by multiplying the price during the peak arrival season and the total quantity of raw chillies materials used. The annual total cost of processing was Rs.14.89 lakhs. The gross return was estimated for production of chillies sauce was Rs. 19.20 lakhs/year. Here the market price of dry chilli sauce product was used as Rs. 40/pocket. It was further found that cost of production of chilli sauce was Rs. 31.02/ pocket (200 gm/pocket). Further, the profit earned was estimated as Rs. 8.98 per pocket of chilli sauce product.

\section{Optimization by TORA}

TORA software used in optimizartion problem. The variables uses are Chillies powder and Chillies Sauce and constraints used are human labour requirement/unit;capital requirement/unit and demand for respective products. The available resources are as resource constraint. The results shown Chillies powder production was only economical. Hence the software suggested to stop the Chillies sauce production. The linear programming indicted that 47,945 Chillies powder pockets/year should be produced @ 160 pockets (200 gm pockets) per day. It fetched the gross income accounting for Rs.21.57 lahks /year.

\section{CONCLUSIONS}

It was inferred from the study that the initial investment expenditure in Chillies powder production was Rs. 16.55 lakhs. The annual total cost of processing was Rs.14.47 lakhs. The gross return was estimated for production of chillies powder was Rs. 21.60 lakhs/year. The annual total cost of processing was Rs.14.89 lakhs. The gross return was estimated for production of chillies sauce was Rs. 19.20 lakhs/year only. In optimization of the industry resources analysis, it was 
inferred that 47,945 Chillies powder pockets/year should be produced @ 160 pockets(200 gm pockets) per day. It fetched the gross income accounting for Rs.21.57 lahks /year. It was found that Chillies powder production was only economical. Hence the software suggested to stop the Chillies sauce production. Economic utilization of available resources would pave the way for supply chain optimization systems to ensure efficient utilization of resources and maximization of gross income. The establishment of rural chillies processing industry as a cooperative venture, covering about 1000 chillies growers (5-10 villages) was also found to be economically viable. This approach would be beneficial to the entrepreneurs by providing necessary profit and consumers by providing reasonable price.

\section{REFERENCES}

1. Srivastava.S.K, Sivaramane.N, Mathur.V.C," Diagnosis of chillies performance of India” Agricultural Economics Research Review, 23,137-148,2010.

2. Devaraj, " Growth performance of chillies: a zone-wise analysis", Agricultural Situation in India, 2007, 297-301

3. Singh, Harbant., et al. "Performance of Five Plant Extract On-Leaf-Cuttingbeetle Hypomeces squamosus on Harumanis Variety of Mango in Perlis, Malaysia." International Journal of Agricultural Science and Research (IJASR) 3.1 (2013): 89-98.

4. Joel D. Wishner,G.Keong Leong and Keah-Choon Tan, "Principles of Supply chain management- A balance approach", Cengage Learning India Pvt.Ltd.,NewDelhi,2005.

5. Bhagoria, J L, and Sanjeev Kumar Yadav. "A Comparison between Natural and Solar Drying of Banana Chips and Chilly Drying Using Smooth and Artificially Roughened Absorber Plate in Solar Air Heater." International Journal of Mechanical and Production Engineering Research and Development (IJMPERD) 9. 1, Feb 2019, 51 -58

6. Durgabai, R. P. L., and P. Bhargavi. "Pest Management using Machine Learning Algorithms: A Review." International Journal of Computer Science Engineering and Information Technology Research (IJCSEITR) 8.1 (2018): 13-22.

7. Ramakrishna, N., and P. Surshbabu. "Ethno-Medico-Botany of Some Sacred Groves of Adilabad District of Telangana State." International Journal of General Medicine and Pharmacy (IJGMP) 8. 1, Dec - Jan 2019; 1-8 

